Volume 8, No.2, March - April 2019

International Journal of Advanced Trends in Computer Science and Engineering

Available Online at http://www.warse.org/IJATCSE/static/pdf/file/ijatcse15822019.pdf https://doi.org/10.30534/ijatcse/2019/15822019

\title{
An Innovative Design of a Solar-Wind Hybrid System
}

\author{
Parag Nijhawan \\ EIED,TIET, Patiala, India \\ parag.nijhawan@rediffmail.com
}

\author{
Amandeep Singh Oberoi \\ MED,TIET, Patiala, India \\ oberoi@thapar.edu
}

\begin{abstract}
Continuously diminishing fossil fuel reservoirs and limited land area for energy harnessing has compelled researchers to shift their focus towards renewable energy. Though these resources are available in abundance but, even the best available energy harnessing technologies are not mature enough to yield the best efficiencies in terms of energy harnessing/m2 of the land deployed. The present paper focuses on the innovative design of a hybrid Solar-Wind system to exploit the better energy harnessing per sq. $\mathrm{m}$. of land where both the solar and wind energy resources are available in abundance. A theoretical study on implication of the hybrid design is carried out at the selected locations of Umrala and Haripar in India. The solar irradiance and wind velocity data for the last three decades for these sites are collected using PVsyst software. The yielded results would definitely result in effective utilization of land, and increase in energy density.
\end{abstract}

Key words: solar energy, wind energy, hybrid system, renewable energy harnessing, sustainable development

\section{INTRODUCTION}

Exploring alternate fuels, neutralising the effects of pollution, and controlling the emission rates are some of the key challenges that need to be addressed in the near future for a sustainable development [1-3]. The industrial revolution and globalization has led to the increased dependency on energy. Conventional fossil-based fuels have been major contributors in catering the energy needs for past many decades. Consequently emissions levels have grown-up exponentially resulting in global environmental threats like acid rain, increased airpollution, global warming etc. Recognising the need of hour, global economies are set to shift to alternate energy sources [4-6]. But most of the renewable sources of energy are not being tapped or harnessed to a significant extent. Moreover, these sources are not available continuously round the clock. One alternative to this problem is to store the renewable energy [7-9] in addition to utilizing it when it is available in abundance, and then to utilize this stored energy during the off-periods i.e. when the natural source is not available. The reliability of the renewable energy conversion systems also improve if one can tap more than one renewable energy source and come out with a hybrid system. The energy conversion efficiency of the renewable energy systems is also low. So, a lot of land area gets blocked in the installation of energy harnessing equipment like solar cell arrays, wind turbines, etc. In this direction, an attempt is being made to propose an innovative design of Solar-Wind hybrid system that could yield better results in terms of energy harnessing efficiency and energy production per unit space occupied. In this proposed design, two arrays of solar PVs are installed around the periphery of the stem/tower of a horizontal-axis wind turbine in addition to installing them on the stem itself. To explore the viability of the proposed system, a detailed theoretical and simulation studies are carried out in PVsyst software and reported. The proposed system studies are implemented for the selected sites viz. Umrala and Haripar in India. The selected sites parameters are used to have the power generation and its variance throughout the year.

\section{SYSTEM DESCRIPTION}

A typical horizontal-axis wind turbine, an array of 3rd generation silicon solar cells, and a set of lithium-ion battery constitutes to form a hybrid system. To complete the electrical circuit certain accessories like converter circuit and controller were also added to the system as shown in Figure 1. Two numbers of racks to contain flexible solar cells are arranged in a particular fashion around the stem of wind turbine which looks like 2 distant rings around the tower. The rings of solar cells around the stem are inclined to the horizontal at an angle to avoid the shadow and hence, tap the solar rays to the maximum extent at a particular instant. To enhance the energy harnessing capability per unit of land deployed, flexible solar cells were also wrapped around the stem beside the dual-ring arrangement. The wrapping of flexible solar cells around wind turbine stem was above all the rings to ensure their maximum utilization. The horizontal-axis wind turbine considered in the present work was of $110 \mathrm{~m}$ height and the rings at $30 \mathrm{~m}$ and $50 \mathrm{~m}$ height respectively.

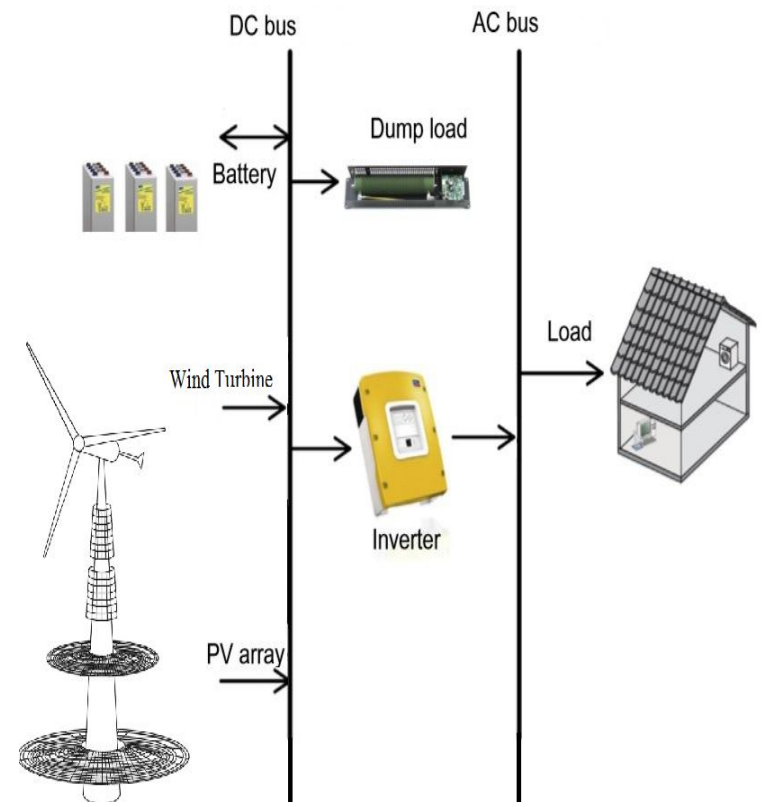

Figure 1:Schematic of the proposed solar-wind hybrid system. 
Similar to other renewable energy harnessing systems, the output from all the installed solar cells as well as the wind turbine was fed to a DC bus. The electronic load was connected to the proposed hybrid system which could be driven from either of the available sources (i.e. wind or solar). For storage of access electricity during peakgeneration hours, energy was stored in a bank of lithiumion batteries to meet the energy demand when renewable sources are unavailable. When energy from either of the systems is available, it drives the electronic load. The excess energy generated during peak wind or solar or both, gets stored in the battery bank to meet the power demand during off-peak generation. AC load demand was met by converting the produced DC power into AC through a converter circuit.

Usually, renewable-based hybrid systems combine the output from the independent units connected to the DC bus. However, fewer considerations are made toward the overall energy harness output per $\mathrm{m} 2$ of the land occupied. Therefore, to overcome the anomalies of the conventional systems a novel design of solar-wind hybrid system is proposed that would yield better energy harnessing efficiency in terms of per unit land utilization. The efficiency of any given solar cells/module/array depends on the following factors:

- The cleanliness of the solar cells i.e. dust free or obstacle free environment.

- Low operating temperature.

- Effectiveness of the cooling arrangement for the cell, and

- The time of exposure to the sun radiation incident on the cell.

The combination of the two individual renewable energy harnessing units could favour all the above mentioned factors thereby enhancing the operating efficiency of the installed solar cells. The rotating blades of a horizontal axis wind turbine not only generate enough draft to avoid deposition of dust on solar cells but also help cooling down the solar cells. The primary function of a typical solar cell is to convert light energy of sun into electricity through photon bombardment on silicon crystals. But, unfortunately the solar incident rays do posses infrared spectrum which is responsible of generating heat which lowers the efficiency of solar cells. So it is absolutely necessary to maintain the operating temperature of a solar cell within the permissible limits so as to achieve higher efficiency. The inclined design of the rings and wrapping of solar cells around stem of wind turbine would allow solar cell exposure to direct sunlight for maximum time thereby increasing the yielding capacity of these cells.

\section{SITE ANALYSIS}

For the feasibility study of the proposed hybrid system, two sites were considered where both solar and wind energy is available in abundance. One of the selected sites is Umrala located at $21^{\circ} 50^{\prime} 0^{\prime \prime} \mathrm{N}$ latitude and $71^{\circ} 49^{\prime} 0^{\prime \prime} \mathrm{E}$ longitude and the other is Haripar located at 23.6315 latitude and 68.9742 longitude, respectively, both in Gujarat state of India. Gujarat being the coastal area experience high wind drafts round-the-year besides receiving the high solar irradiance due to the Tropic of Cancer passing through it. Due to these reasons, Gujarat offers advantages to the proposed hybrid system, and was ideal for the presented study. The solar irradiance and wind velocity data for the last three decades for the selected sites was collected using PVsyst software. The input parameters inserted in the PVsyst are given in Fig. 2. The angle of tilt considered here is the angle at which the solar cell array is mounted on the wind turbine stem with respect to the horizontal.

The maximum power point (MPP) curve was obtained from the PVsyst software against the inserted input parameters for the proposed solar cell array around the stem of the wind turbine. The obtained curve helped assessing the maximum power generation capability of the proposed system. The results allowed estimating the power sizing and hence inverter output distribution system. Fig. 2 and Fig. 3 show change in the solar azimuth angle for the selected sites i.e. Umrala and Haripar, respectively.

It is evitable to study the solar behaviour of the selected site in order to assess the performance of the proposed hybrid systems. In lieu to this, analysis of sun-earth angle, solar azimuth angle in particular, was performed through PVsyt. The effect of variation in solar azimuth angle on the selected tilted planes $\left(30^{\circ}\right.$ with respect to the horizontal) is shown in Figure 2 and Figure. 3.

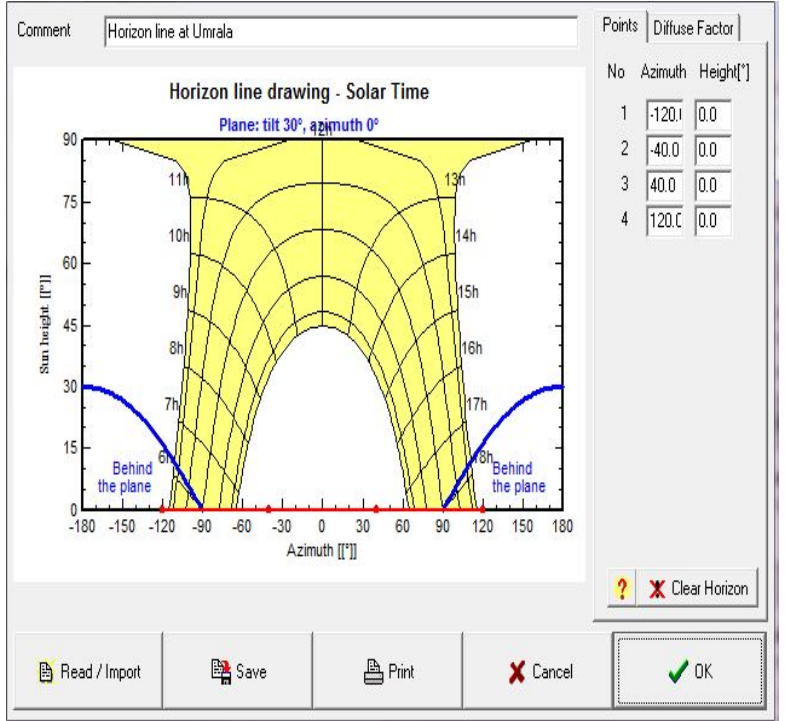

Figure 2: The effect of variation in solar azimuth angle on the selected tilted plane i.e. Umrala

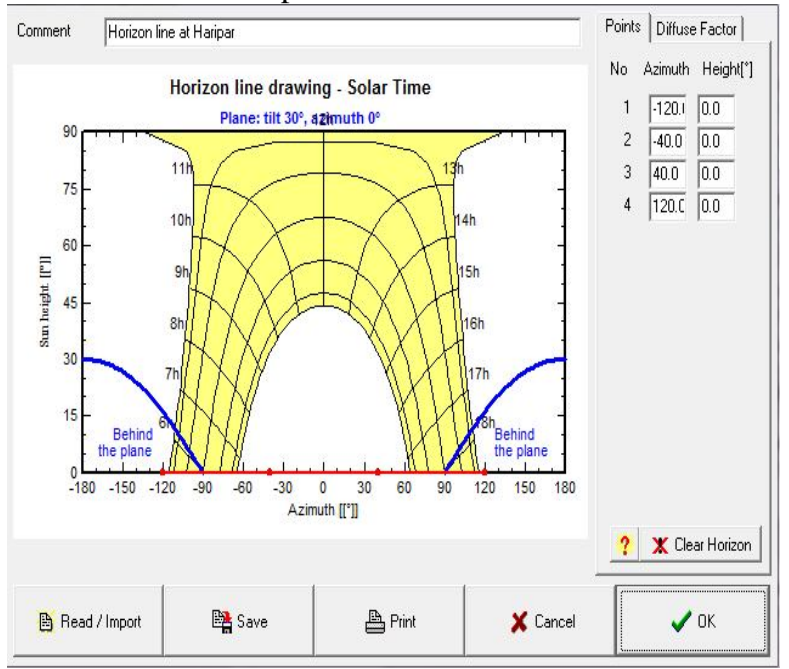

Figure 3: The effect of variation in solar azimuth angle on the selected tilted plane i.e. Haripar. 
Umrala varied from 129.6 - $221.0 \mathrm{kWh} / \mathrm{m} 2$ whereas at Haripar it was found in the range of $137.0-225.4 \mathrm{~kW} / \mathrm{m} 2$. Table 3 and table 4 represent the annual wind trends and global incidence data of the selected sites i.e., Umrala and Haripar, respectively. The obtained annual wind velocity trends would assist in designing an efficient and durable horizontal-axis wind turbine that is most suitable for the proposed hybrid system. The wind velocity varies through-out the year from $1.3-4.0 \mathrm{~m} / \mathrm{s}$ with an average value of $2.5 \mathrm{~m} / \mathrm{s}$ at Umrala and from 1.8-5.4 m/s with an average value of $3.5 \mathrm{~m} / \mathrm{s}$ at Haripar.

Table 1: Annual meteorological and incident data for Umrala

\begin{tabular}{lllllllll}
\hline Month & $\begin{array}{l}\text { GlobHor } \\
\mathrm{kWh} / \mathrm{m} 2\end{array}$ & $\begin{array}{l}\mathrm{T} \mathrm{Amb} \\
\mathrm{oC}\end{array}$ & $\begin{array}{l}\text { GlobInc } \\
\mathrm{kWh} / \mathrm{m} 2\end{array}$ & $\begin{array}{l}\text { GlobEff } \\
\mathrm{kWh} / \mathrm{m} 2\end{array}$ & $\begin{array}{l}\text { EArray } \\
\mathrm{kWh}\end{array}$ & $\begin{array}{l}\text { E_Grid } \\
\mathrm{kWh}\end{array}$ & $\begin{array}{l}\text { EffArrR } \\
\%\end{array}$ & $\begin{array}{l}\text { EffSysR } \\
\%\end{array}$ \\
\hline January & 160.8 & 20.89 & 224.5 & 220.4 & 389.5 & 376.9 & 9.65 & 9.34 \\
February & 162.0 & 23.46 & 202.5 & 198.5 & 347.0 & 335.6 & 9.54 & 9.23 \\
March & 213.6 & 27.67 & 235.7 & 230.7 & 391.3 & 378.2 & 9.24 & 8.93 \\
April & 209.8 & 30.12 & 203.8 & 198.0 & 344.5 & 332.9 & 9.40 & 9.09 \\
May & 221.0 & 31.63 & 195.0 & 188.6 & 334.4 & 323.0 & 9.54 & 9.22 \\
June & 180.9 & 30.39 & 154.9 & 149.2 & 273.3 & 263.7 & 9.82 & 9.48 \\
July & 140.0 & 28.70 & 123.8 & 119.1 & 224.1 & 215.8 & 10.07 & 9.70 \\
August & 129.6 & 27.65 & 120.7 & 116.4 & 218.5 & 210.4 & 10.08 & 9.70 \\
September & 166.4 & 28.01 & 171.7 & 166.7 & 302.3 & 292.2 & 9.80 & 9.47 \\
October & 177.9 & 28.75 & 212.1 & 207.0 & 361.5 & 349.7 & 9.49 & 9.18 \\
November & 155.4 & 25.68 & 208.5 & 204.6 & 356.5 & 344.7 & 9.51 & 9.20 \\
December & 146.5 & 22.70 & 208.9 & 205.0 & 363.9 & 351.9 & 9.70 & 9.38 \\
Year & 2063.7 & 27.15 & 2262.1 & 2204.3 & 3906.8 & 3775.2 & 9.61 & 9.29 \\
\hline
\end{tabular}

Table 2: Annual meteorological and incident data for Haripar

\begin{tabular}{lllllllll}
\hline Month & $\begin{array}{l}\text { GlobHor } \\
\mathrm{kWh} / \mathrm{m} 2\end{array}$ & $\begin{array}{l}\text { T Amb } \\
\mathrm{oC}\end{array}$ & $\begin{array}{l}\text { GlobInc } \\
\mathrm{kWh} / \mathrm{m} 2\end{array}$ & $\begin{array}{l}\text { GlobEff } \\
\mathrm{kWh} / \mathrm{m} 2\end{array}$ & $\begin{array}{l}\text { EArray } \\
\mathrm{kWh}\end{array}$ & $\begin{array}{l}\text { E_Grid } \\
\mathrm{kWh}\end{array}$ & $\begin{array}{l}\text { EffArrR } \\
\%\end{array}$ & $\begin{array}{l}\text { EffSysR } \\
\%\end{array}$ \\
\hline January & 159.5 & 20.43 & 224.3 & 220.3 & 468.0 & 452.4 & 9.68 & 9.35 \\
February & 162.3 & 23.31 & 204.2 & 200.3 & 418.1 & 404.1 & 9.50 & 9.18 \\
March & 212.2 & 27.95 & 235.1 & 230.3 & 466.3 & 450.4 & 9.20 & 8.89 \\
April & 200.6 & 30.67 & 195.9 & 189.8 & 398.0 & 384.6 & 9.42 & 9.11 \\
May & 225.4 & 32.25 & 199.7 & 193.1 & 406.7 & 392.8 & 9.44 & 9.12 \\
June & 188.5 & 30.91 & 162.5 & 156.6 & 342.1 & 330.5 & 9.76 & 9.43 \\
July & 139.3 & 28.76 & 123.9 & 119.2 & 268.6 & 259.1 & 10.05 & 9.69 \\
August & 137.0 & 27.46 & 128.3 & 123.8 & 279.0 & 269.2 & 10.08 & 9.73 \\
September & 164.6 & 28.03 & 171.1 & 166.2 & 361.4 & 349.2 & 9.79 & 9.46 \\
October & 176.0 & 29.46 & 211.6 & 206.6 & 432.1 & 417.7 & 9.47 & 9.16 \\
November & 151.4 & 26.13 & 204.7 & 200.7 & 421.3 & 407.0 & 9.54 & 9.22 \\
December & 145.5 & 22.47 & 210.7 & 206.8 & 441.7 & 426.9 & 9.72 & 9.40 \\
Year & 2062.1 & 27.33 & 2272.0 & 2213.5 & 4703.3 & 4543.8 & 9.60 & 9.27 \\
\hline
\end{tabular}

Table 3: Annual wind and global incidence data for Umrala

\begin{tabular}{lllllllll}
\hline Month & $\begin{array}{l}\text { GlobHor } \\
\mathrm{kWh} / \mathrm{m} 2\end{array}$ & $\begin{array}{l}\text { DiffHor } \\
\mathrm{kWh} / \mathrm{m} 2\end{array}$ & $\begin{array}{l}\text { GlobInc } \\
\mathrm{kWh} / \mathrm{m} 2\end{array}$ & $\begin{array}{l}\text { T Amb } \\
\mathrm{oC}\end{array}$ & $\begin{array}{l}\text { WindVel } \\
\mathrm{m} / \mathrm{s}\end{array}$ & $\begin{array}{l}\text { DifSInc } \\
\mathrm{kWh} / \mathrm{m} 2\end{array}$ & $\begin{array}{l}\text { Alb Inc } \\
\mathrm{kWh} / \mathrm{m} 2\end{array}$ & DifS/GI \\
\hline January & 160.8 & 23.56 & 224.5 & 20.89 & 1.8 & 29.76 & 2.154 & 0.000 \\
February & 162.0 & 33.77 & 202.5 & 23.46 & 1.9 & 40.01 & 2.170 & 0.000 \\
March & 213.6 & 39.72 & 235.7 & 27.67 & 2.2 & 43.39 & 2.862 & 0.000 \\
April & 209.8 & 63.73 & 203.8 & 30.12 & 2.9 & 63.47 & 2.810 & 0.000 \\
May & 221.0 & 80.94 & 195.0 & 31.63 & 4.0 & 75.74 & 2.947 & 0.000 \\
June & 180.9 & 92.93 & 154.9 & 30.39 & 3.9 & 83.65 & 2.415 & 0.000 \\
July & 140.0 & 97.22 & 123.8 & 28.70 & 3.7 & 87.58 & 1.875 & 0.000 \\
August & 129.6 & 87.05 & 120.7 & 27.65 & 3.3 & 80.88 & 1.736 & 0.000 \\
September & 166.4 & 79.40 & 171.7 & 28.01 & 2.4 & 79.78 & 2.229 & 0.000 \\
October & 177.9 & 54.78 & 212.1 & 28.75 & 1.5 & 62.45 & 2.383 & 0.000 \\
November & 155.4 & 33.12 & 208.5 & 25.68 & 1.3 & 40.72 & 2.082 & 0.000 \\
December & 146.5 & 29.20 & 208.9 & 22.70 & 1.5 & 37.02 & 1.963 & 0.000 \\
Year & 2063.7 & 715.42 & 2262.1 & 27.15 & 2.5 & 724.46 & 27.626 & 0.000 \\
\hline
\end{tabular}

Table 4: Annual wind and global incidence data for Haripar

\begin{tabular}{lllllllll}
\hline Month & $\begin{array}{l}\text { GlobHor } \\
\mathrm{kWh} / \mathrm{m} 2\end{array}$ & $\begin{array}{l}\text { DiffHor } \\
\mathrm{kWh} / \mathrm{m} 2\end{array}$ & $\begin{array}{l}\text { GlobInc } \\
\mathrm{kWh} / \mathrm{m} 2\end{array}$ & $\begin{array}{l}\mathrm{T} \text { Amb } \\
\mathrm{oC}\end{array}$ & $\begin{array}{l}\text { WindVel } \\
\mathrm{m} / \mathrm{s}\end{array}$ & $\begin{array}{l}\text { DifSInc } \\
\mathrm{kWh} / \mathrm{m} 2\end{array}$ & $\begin{array}{l}\text { Alb Inc } \\
\mathrm{kWh} / \mathrm{m} 2\end{array}$ & DifS/GI \\
\hline January & 159.5 & 23.00 & 224.3 & 20.43 & 2.4 & 29.21 & 9.68 & 0.000 \\
February & 162.3 & 31.33 & 204.2 & 23.31 & 2.6 & 37.13 & 9.50 & 0.000 \\
March & 212.2 & 40.41 & 235.1 & 27.95 & 3.1 & 44.04 & 9.20 & 0.000 \\
April & 200.6 & 74.41 & 195.9 & 30.67 & 4.1 & 74.04 & 9.42 & 0.000 \\
May & 225.4 & 80.52 & 199.7 & 32.25 & 5.4 & 75.64 & 9.44 & 0.000 \\
June & 188.5 & 97.70 & 162.5 & 30.91 & 5.2 & 88.04 & 9.76 & 0.000 \\
July & 139.3 & 97.74 & 123.9 & 28.76 & 4.8 & 88.24 & 10.05 & 0.000 \\
August & 137.0 & 94.25 & 128.3 & 27.46 & 4.4 & 87.65 & 10.08 & 0.000 \\
September & 164.6 & 78.92 & 171.1 & 28.03 & 3.5 & 79.78 & 9.79 & 0.000 \\
\hline
\end{tabular}


Parag Nijhawan, et al., International Journal of Advanced Trends in Computer Science and Engineering, 8(2), March - April 2019,203 - 207

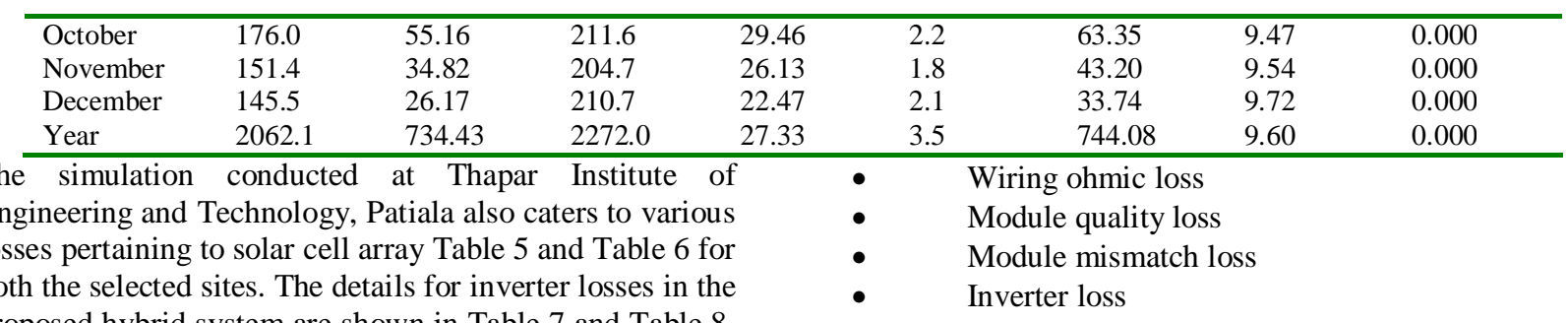
proposed hybrid system are shown in Table 7 and Table 8. The various incurred solar cell losses are:

Table 5: Annual system losses for the proposed system considering the selected site i.e. Umrala

\begin{tabular}{llllll}
\hline Month & $\begin{array}{l}\text { ModQual } \\
\mathrm{kWh}\end{array}$ & $\begin{array}{l}\text { MisLoss } \\
\mathrm{kWh}\end{array}$ & $\begin{array}{l}\text { OhmLoss } \\
\mathrm{kWh}\end{array}$ & $\begin{array}{l}\text { EArrMPP } \\
\mathrm{kWh}\end{array}$ & $\begin{array}{l}\text { InvLoss } \\
\mathrm{kWh}\end{array}$ \\
\hline January & 6.186 & 4.062 & 5.841 & 396.3 & 19.48 \\
February & 5.499 & 3.611 & 5.208 & 352.3 & 16.63 \\
March & 6.230 & 4.091 & 6.121 & 398.9 & 20.70 \\
April & 5.394 & 3.542 & 4.658 & 346.0 & 13.03 \\
May & 5.205 & 3.418 & 3.973 & 334.4 & 11.39 \\
June & 4.244 & 2.787 & 2.631 & 273.3 & 9.55 \\
July & 3.473 & 2.281 & 1.731 & 224.1 & 8.24 \\
August & 3.389 & 2.225 & 1.803 & 218.5 & 8.14 \\
September & 4.715 & 3.096 & 3.486 & 303.0 & 10.81 \\
October & 5.673 & 3.725 & 4.995 & 363.8 & 14.12 \\
November & 5.627 & 3.695 & 5.250 & 360.6 & 15.91 \\
December & 5.732 & 3.764 & 5.234 & 367.4 & 15.45 \\
Year & 61.367 & 40.298 & 50.931 & 3938.6 & 163.46 \\
\hline
\end{tabular}

Table 6:. Annual system losses for the proposed system considering the selected site i.e. Haripar

\begin{tabular}{llllll}
\hline Month & $\begin{array}{l}\text { ModQual } \\
\mathrm{kWh}\end{array}$ & $\begin{array}{l}\text { MisLoss } \\
\mathrm{kWh}\end{array}$ & $\begin{array}{l}\text { OhmLoss } \\
\mathrm{kWh}\end{array}$ & $\begin{array}{l}\text { EArrMPP } \\
\mathrm{kWh}\end{array}$ & $\begin{array}{l}\text { InvLoss } \\
\mathrm{kWh}\end{array}$ \\
\hline January & 7.430 & 4.879 & 7.028 & 476.0 & 23.61 \\
February & 6.645 & 4.364 & 6.379 & 425.6 & 21.55 \\
March & 7.434 & 4.882 & 7.369 & 475.9 & 25.56 \\
April & 6.209 & 4.077 & 5.128 & 398.5 & 13.95 \\
May & 6.332 & 4.158 & 4.959 & 406.7 & 13.86 \\
June & 5.314 & 3.489 & 3.355 & 342.1 & 11.62 \\
July & 4.163 & 2.734 & 2.104 & 268.6 & 9.49 \\
August & 4.328 & 2.842 & 2.333 & 279.0 & 9.81 \\
September & 5.629 & 3.697 & 4.150 & 361.8 & 12.59 \\
October & 6.769 & 4.445 & 5.946 & 434.1 & 16.40 \\
November & 6.631 & 4.354 & 6.058 & 425.0 & 18.01 \\
December & 6.950 & 4.564 & 6.309 & 445.5 & 18.65 \\
Year & 73.834 & 48.484 & 61.117 & 4738.9 & 195.11 \\
\hline
\end{tabular}

Table 7: Annual inverter losses for the proposed system considering the selected site i.e. Umrala

\begin{tabular}{lllllllll}
\hline Month & $\begin{array}{l}\text { EOutInv } \\
\mathrm{kWh}\end{array}$ & $\begin{array}{l}\text { EffInvR } \\
\%\end{array}$ & $\begin{array}{l}\text { InvLoss } \\
\mathrm{kWh}\end{array}$ & $\begin{array}{l}\text { IL Oper } \\
\mathrm{kWh}\end{array}$ & $\begin{array}{l}\mathrm{IL} \text { Pmin } \\
\mathrm{kWh}\end{array}$ & $\begin{array}{l}\text { IL Pmax } \\
\mathrm{kWh}\end{array}$ & $\begin{array}{l}\text { IL Vmin } \\
\mathrm{kWh}\end{array}$ & $\begin{array}{l}\text { IL Vmax } \\
\mathrm{kWh}\end{array}$ \\
\hline January & 376.9 & 96.8 & 19.48 & 12.60 & 0.000 & 0.000 & 6.876 & 0.000 \\
February & 335.6 & 96.7 & 16.63 & 11.38 & 0.000 & 0.000 & 5.249 & 0.000 \\
March & 378.2 & 96.7 & 20.70 & 13.10 & 0.000 & 0.000 & 7.603 & 0.000 \\
April & 332.9 & 96.7 & 13.03 & 11.51 & 0.000 & 0.000 & 1.521 & 0.000 \\
May & 323.0 & 96.6 & 11.39 & 11.37 & 0.000 & 0.000 & 0.019 & 0.000 \\
June & 263.7 & 96.5 & 9.55 & 9.55 & 0.000 & 0.000 & 0.000 & 0.000 \\
July & 215.8 & 96.3 & 8.24 & 8.24 & 0.000 & 0.000 & 0.000 & 0.000 \\
August & 210.4 & 96.3 & 8.14 & 8.14 & 0.000 & 0.000 & 0.000 & 0.000 \\
September & 292.2 & 96.7 & 10.81 & 10.09 & 0.000 & 0.000 & 0.717 & 0.000 \\
October & 349.7 & 96.7 & 14.12 & 11.78 & 0.000 & 0.000 & 2.341 & 0.000 \\
November & 344.7 & 96.7 & 15.91 & 11.83 & 0.000 & 0.000 & 4.087 & 0.000 \\
December & 351.9 & 96.7 & 15.45 & 11.99 & 0.000 & 0.000 & 3.464 & 0.000 \\
Year & 3775.2 & 96.6 & 163.46 & 131.59 & 0.000 & 0.000 & 31.877 & 0.000 \\
\hline
\end{tabular}


Table 8: Annual inverter losses for the proposed system considering the selected site i.e. Haripar

\begin{tabular}{lllllllll}
\hline Month & $\begin{array}{l}\text { EOutInv } \\
\mathrm{kWh}\end{array}$ & $\begin{array}{l}\text { EffInvR } \\
\%\end{array}$ & $\begin{array}{l}\text { InvLoss } \\
\mathrm{kWh}\end{array}$ & $\begin{array}{l}\text { IL Oper } \\
\mathrm{kWh}\end{array}$ & $\begin{array}{l}\text { IL Pmin } \\
\mathrm{kWh}\end{array}$ & $\begin{array}{l}\text { IL Pmax } \\
\mathrm{kWh}\end{array}$ & $\begin{array}{l}\text { IL Vmin } \\
\mathrm{kWh}\end{array}$ & $\begin{array}{l}\text { IL Vmax } \\
\mathrm{kWh}\end{array}$ \\
\hline January & 452.4 & 20.43 & 23.61 & 16.83 & 0.000 & 0.000 & 6.781 & 0.000 \\
February & 404.1 & 23.31 & 21.55 & 14.96 & 0.000 & 0.000 & 6.593 & 0.000 \\
March & 450.4 & 27.95 & 25.56 & 19.75 & 0.000 & 0.000 & 5.812 & 0.000 \\
April & 384.6 & 30.67 & 13.95 & 12.28 & 0.000 & 0.000 & 1.675 & 0.000 \\
May & 392.8 & 32.25 & 13.86 & 13.74 & 0.000 & 0.000 & 0.126 & 0.000 \\
June & 330.5 & 30.91 & 11.62 & 11.62 & 0.000 & 0.000 & 0.000 & 0.000 \\
July & 259.1 & 28.76 & 9.49 & 9.49 & 0.000 & 0.000 & 0.000 & 0.000 \\
August & 269.2 & 27.46 & 9.81 & 9.81 & 0.000 & 0.000 & 0.000 & 0.000 \\
September & 349.2 & 28.03 & 12.59 & 12.15 & 0.000 & 0.000 & 0.447 & 0.000 \\
October & 417.7 & 29.46 & 16.40 & 14.25 & 0.000 & 0.000 & 2.154 & 0.000 \\
November & 407.0 & 26.13 & 18.01 & 15.13 & 0.000 & 0.000 & 2.882 & 0.000 \\
December & 426.9 & 22.47 & 18.65 & 16.01 & 0.000 & 0.000 & 2.643 & 0.000 \\
Year & 4543.8 & 27.33 & 195.11 & 166.02 & 0.000 & 0.000 & 29.113 & 0.000 \\
\hline
\end{tabular}

The simulation also details about the enhancement in energy harnessing by mounting solar cell array around the stem of a horizontal-axis wind turbine.

\section{CONCLUSION}

The proposed solar-wind hybrid system with site location of Umrala and Haripar, Gujarat is a feasible fit due to availability of both solar and wind energy. A simulation was conducted by inserting fixed variable inputs to assess the technical feasibility of the overall system. The simulation results as mentioned in the preceding sections were found to be within the acceptable limits. The obtained results would pave a way forward towards developing a more sustainable, effective and rugged hybrid renewable energy systems that could cater the energy needs of the Indian sub-continent and similar geographical locations.

\section{Conflict of Interest}

The authors of the presented manuscript have contributed significantly in the research work and hereby declare no conflict of interest. The authors mutually agree on the order of name of authors for the presented manuscript.

\section{Data Availability Statement}

The data for the selected sites i.e., Umrala and Haripar, have been acquired using the PVsyst software. The feasilbility studies for these sites have been carried out to install the proposed design of hybrid solar-wind system to improve the energy harnessing $/ \mathrm{m}^{2}$.

\section{Funding Statement}

The research presented in this manuscript has been carried out at Thapar Institute of Engineering \& Technology, Patiala (INDIA). The institute has well equipped laboratories and infrastructure to support this research.

\section{REFERENCES}

[1] I.A Adejumobi, S.G. Oyagbinrin, F.G. Akinboro, M.B. Olajide, "Hybrid solar and wind power: an essential for information communication technology infrastructure and people in rural communities", IJRRAS 9, no. 1 (2011) 130-138.
[2] K. Sharma, P. Haksar, "Designing of Hybrid Power Generation System using Wind Energy-Photovoltaic Solar Energy-Solar Energy with Nanoantenna", International Journal of Engineering Research and Applications (IJERA)2, no. 1 (2012) 812-815.

[3] S. Kumar, V.K. Garg, "A hybrid model of solar-wind power generation system", International Journal of Advanced Research in Electrical, Electronics and Instrumentation Engineering (IJAREEIE)2,no.8 (2013) 4107-4016.

https://doi.org/10.15662/IJAREEIE.2013.0203020

[4] Y. Shivrath, P.B. Narayana, S. Thirumalasetty, D.E.L. Narsaiah, "Design \& integration of wind-solar hybrid energy system for drip irrigation pumping application", International Journal of Modern Engineering Research (IJMER) 2, no. 4 (2012) 2947-2950. [5] A.K. Arjun, S. Athul, M. Ayub, N. Ramesh, A. Krishnan, "Micro-Hybrid Power Systems-A Feasibility Study", Journal of clean Energy technologies 1, no. 1 (2013) 27-32.

https://doi.org/10.7763/JOCET.2013.V1.7

[6] J.B.V. Subrahmanyam, P.K. Sahoo, M. Reddy, 'Local PV-Wind hybrid systems development for supplying electricity to industry", Acta Electrotechnica 53, no. 1 (2012) 10-15.

[7] N. Sivaramakrishna, C.K.R. Reddy, "Hybrid Power Generation through combined solar-wind power and modified solar panel", International Journal of Engineering Trends and Technology 4, no. 5 (2013) 14141417.

[8] Y. Sawle, S.C. Gupta, A.K. Bohre, 'PV-wind hybrid system: A review with case study", Cogent Engineering 3, no. 1 (2016) 1189305.

https://doi.org/10.1080/23311916.2016.1189305

[9] S. Khisa, R. Ebihara, T. Dei, "Dynamics of a grid connected hybrid wind-solar and battery system: Case study in Naivasha-Kenay”, Energy Procedia138 (2017), 680-685.

https://doi.org/10.1016/j.egypro.2017.10.200 